
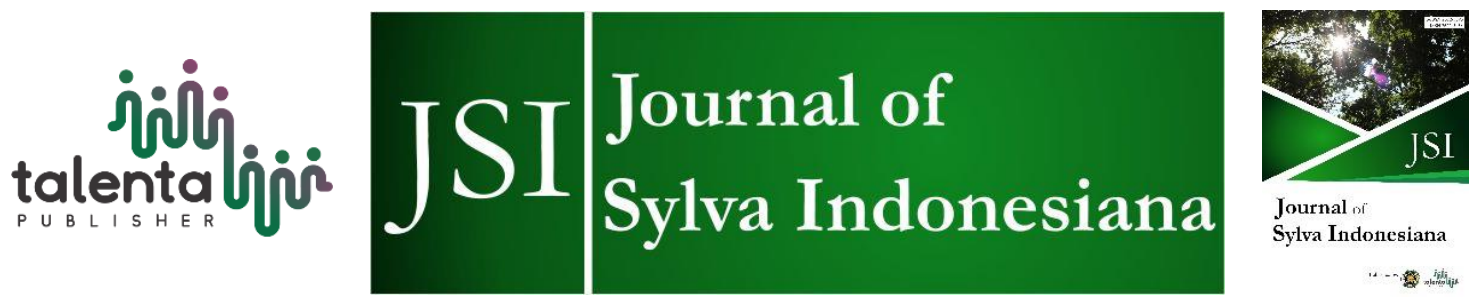

\title{
Biological and Cultural Ecotourism Interpretation of Mekar Utama Village, Kendawangan District, West Kalimantan
}

\author{
Sarma Siahaan $^{1}$, Reine Suci Wulandari ${ }^{1 *}$, Andre Sidabutar ${ }^{1}$, and \\ Muflihati $^{1}$ \\ ${ }^{I}$ Fakultas Kehutanan, Universitas Tanjungpura, Jl. Daya Nasional, Pontianak 78124, Indonesia
}

\begin{abstract}
Mekar Utama Village, located in the Ketapang Industrial Forest Area (Hutan Ketapang Industri-HKI), is a unique and attractive ecotourism site with various natural resources. This village's three hamlets have the potential for biological and cultural ecotourism. The study aims to obtain potential data and interpret the biological and sociocultural ecotourism in Mekar Utama village. The method used was a survey with observation and interview approaches. Three interpretive tracks and 18 biological and cultural ecotourism potential were available at the study site. Nine potential plants found were kantung semar (Nepenthes sp.), bamboo (Bambusa sp.), bajakah (Spatholobus littoralis Hassk), pasak bumi (Eurycoma longifolia Jack), ulin (Eusideroxylon zwageri), meranti (Shorea smithiana), gaharu (Aquilaria malaccensis), ketatai (Antiaris toxicaria) and pulai (Alstonia scholaris). Ulin, meranti, and gaharu are protected species. Kura-kura hutan (Dogania suplana), owa kelawat (Hylobates albibarbis), and honey bee (Apis koschevnikovi and Trigona sp.) were three unique animal species. Six potential cultures were found, i.e. ethnic, traditions, traditional rituals, arts, special foods, historical/sacred places, and folklore/myths. All the potentials were found in three interpretation tracks, i.e., the Gantang river hamlet, which was $6.5 \mathrm{~km}$ long and took 26 minutes to reach, the Sukaria hamlet, which was $5.3 \mathrm{~km}$ long and took 21 minutes, and the Kelukup Belantak hamlet route, which was $\pm 37 \mathrm{~km}$ long and took two hours.
\end{abstract}

Keyword: Ecotourism, Interpretation, Interpretation Tracks

Received 12 July 2021 | Revised 12 October 2021 | Accepted 1 December 2021

\section{Introduction}

Mekar Utama Village, Kelukup Belantak Hamlet, Sukaria Hamlet and Sungai Gentang Hamlet are located in the PT Hutan Ketapang Industri area, Kendawangan District, Ketapang Regency. There are numerous ecosystems in this area. The natural forest is still compact and well managed, it is a high conservation forest with the features of a seven-level waterfall, and the road access is adequate for motorbikes and cars to travel through. Ecotourism is a type of

*Corresponding author at: Fakultas Kehutanan, Universitas Tanjungpura, Jl. Daya Nasional, Pontianak 78124, Indonesia

E-mail address: reine@fahutan.untan.ac.id

Published by Talenta Publisher

ISSN: 2622-5093 e-ISSN: 2622-5158 DOI : 10.32734/jsi.v5i01.6376

Journal Homepage: http://jsi.usu.ac.id 
tourism that involves visiting pristine locations while also offering economic opportunities for local populations to profit from natural and conservation resources [1]. Visitors to Pahmungan Village can follow the interpretative path to visit each tourist attraction one at a time, covering a distance of $2.5 \mathrm{~km}$ [2]. The track of object interpretation is 25 minutes over a distance of $4 \mathrm{~km}$ [3]. Potential interpretation is a communication strategy that helps people make sense of their surroundings [1]. Mekar Utama Village is a protected biological potential (plants and animals) and unique socio-culturally. However, there has not been much research or packaging regarding ecotourism possibilities and detailed interpretations supporting its growth. It is necessary to properly and efficiently collect data and information and produce interpretations. Therefore, tourists as tourism actors can enjoy and obtain associated knowledge in the Mekar Utama hamlet. The abundance of natural resources fosters ecotourism development.

The purpose of the study was to obtain potential data and interpret biological and socio-cultural ecotourism in Mekar Utama village. The findings of this study aid in the development of Mekar Utama village as an informative ecotourism village by providing information about the characteristics of the objects to visitors or tourism actors and stakeholders (forestry service, tourism office, local government, village community).

\section{Research Method}

Mekar Utama village has three hamlets, namely Kelukup Belantak, Sukaria, and Sungai Gantang, which are located in the PT Hutan Ketapang Industri (HKI) area, Kendawangan District. An observational survey was used to conduct the research, including interviews with HKI managers, local communities, traditional elders, the tourism office, and the forestry service. The respondent selection methodology was a purposive sample strategy using structured interviews and observation. Respondents must be at least 17 years old and aware of the location's potential. Location maps, GPS, audio recorder, digital camera, compass, and ArcGIS software are utilized.

Primary data, such as biological potential (plants and animals), and secondary data, such as literature books, documents, photographs, and village monographs, were acquired. An interview question guide has been produced. The questions were about the potential for ecotourism in biological natural resources in terms of types, benefits, uniqueness, rare/protected species, and cultural values. Other socio-cultural information was gathered (ethnicity, traditions, traditional rituals, cultural arts, specific food, historical sites, and folklore/myths). The interviews were then confirmed in the field to ensure that the community's information was correct. The boundary of Kelukup's settlement or hamlet is used to point coordinates.

\subsection{Data processing}

Data were processed by tabulating biological and socio-cultural potential data from the interpretation of ecotourism potential, coordinate points to determine the object's location, and 
the time and distance required to reach the object's location. Thematic maps were created using the ArcGIS software package. Data was analyzed using descriptive qualitative analysis for all ecotourism potentials based on coordinate locations. After that, portrayed in thematic maps and summarized based on conditions and scenarios gathered from various sources.

\section{Results and Discussion}

\subsection{Biological Ecotourism Potential}

\section{A. $\quad$ Plant Potential}

Kantung semar (Nepenthes sp.), bamboo (Bambusa sp.), bajakah (Spatholobus littoralis Hassk), pasak bumi (Eurycoma longifolia Jack), ulin (Eusideroxylon zwageri), meranti (Shorea smithiana), gaharu (Aquilaria malaccensis), ketatai (Antiaris toxicaria) and pulai (Alstonia scholaris) were the nine varieties of potential plants found in Mekar Utama village. Ulin and gaharu are protected plants [4].

Table 1 Potential plants found in Mekar Utama village with the distance of travel time measured from the settlement of Sungai Gantang hamlet

\begin{tabular}{|c|c|c|c|c|c|}
\hline No & Plant & Information & Coordinate point & $\begin{array}{l}\text { Mileage From } \\
\text { Settlement } \\
\text { (Sungai } \\
\text { Gantang } \\
\text { Hamlet) }\end{array}$ & $\begin{array}{l}\text { Travel Time } \\
\text { From } \\
\text { Settlement }\end{array}$ \\
\hline 1. & $\begin{array}{l}\text { Unique Plant } \\
\text { Potential }\end{array}$ & $\begin{array}{l}\text { Kantong } \\
\text { semar } \\
\text { (Nepenthes } \\
\text { sp.) }\end{array}$ & $\begin{array}{l}2^{\circ} 21 ' 29^{\prime \prime} \mathrm{LS} \\
110^{\circ} 16^{\prime} 17^{\prime \prime} \mathrm{BT}\end{array}$ & $\pm 20.600 \mathrm{~km}$ & $\begin{array}{l} \pm 1 \text { hour } 22 \\
\text { min } \\
\text { (motorbike) }\end{array}$ \\
\hline 2. & $\begin{array}{l}\text { The Potential } \\
\text { of Plants Is } \\
\text { Utilized }\end{array}$ & $\begin{array}{l}\text { Bambu } \\
\text { (Bambusa sp) }\end{array}$ & $\begin{array}{l}2^{\circ} 21^{\prime} 27^{\prime \prime ~ L S ~} \\
110^{\circ} 17^{\prime} 9^{\prime \prime} \mathrm{BT}\end{array}$ & $\pm 24.079 \mathrm{~km}$ & $\begin{array}{l} \pm 1 \text { hours } 53 \\
\text { min } \\
\text { (motorbike } \\
\text { and walk) }\end{array}$ \\
\hline \multirow[t]{2}{*}{3.} & $\begin{array}{l}\text { Potential of } \\
\text { Medicinal } \\
\text { Plants }\end{array}$ & $\begin{array}{l}\text { a. Bajakah } \\
\text { (Spatholobus } \\
\text { littoralis } \\
\text { Hassk) }\end{array}$ & $\begin{array}{l}2^{\circ} 19^{\prime} 28^{\prime \prime} \mathrm{LS} \\
110^{\circ} 18^{\prime} 16^{\prime \prime} \mathrm{BT}\end{array}$ & $\pm 28.770 \mathrm{~km}$ & $\begin{array}{l} \pm 2 \text { hours } 21 \\
\text { min } \\
\text { (motorbike } \\
\text { and walk) }\end{array}$ \\
\hline & & $\begin{array}{l}\text { b. Pasak bumi } \\
\text { (Eurycoma } \\
\text { longifolia } \\
\text { Jack) }\end{array}$ & $\begin{array}{l}2^{\circ} 19^{\prime} 54^{\prime \prime} \mathrm{LS} \\
110^{\circ} 17^{\prime} 39^{\prime \prime} \mathrm{BT}\end{array}$ & $\pm 28.670 \mathrm{~km}$ & $\begin{array}{l} \pm 2 \text { hours } 19 \\
\text { min } \\
\text { (motorbike } \\
\text { and walk) }\end{array}$ \\
\hline \multirow[t]{3}{*}{4.} & $\begin{array}{l}\text { Protected } \\
\text { Plant } \\
\text { Potential }\end{array}$ & $\begin{array}{l}\text { a. Ulin } \\
\text { (Eusideroxylo } \\
n \text { zwageri) }\end{array}$ & $\begin{array}{l}2^{\circ} 211^{\prime} 20^{\prime \prime} \mathrm{LS} \\
110^{\circ} 17^{\prime} 13^{\prime \prime} \mathrm{BT}\end{array}$ & $\pm 23.379 \mathrm{~km}$ & $\begin{array}{l} \pm 1 \text { hours } 45 \\
\text { min } \\
\text { (motorbike } \\
\text { and walk) }\end{array}$ \\
\hline & & $\begin{array}{l}\text { b. Meranti } \\
\text { (Shorea } \\
\text { smithiana) }\end{array}$ & $\begin{array}{l}2^{\circ} 21^{\prime} 01,0^{\prime \prime} \mathrm{LS} \\
110^{\circ} 17^{\prime} 14,9^{\prime \prime} \mathrm{BT}\end{array}$ & $\pm 23.879 \mathrm{~km}$ & $\begin{array}{l} \pm 2 \text { hours } 10 \\
\text { min } \\
\text { (motorbike } \\
\text { and walk) }\end{array}$ \\
\hline & & & $\begin{array}{l}2^{\circ} 21^{\prime} 00,1^{\prime \prime} \mathrm{LS} \\
110^{\circ} 17^{\prime} 14,6^{\prime \prime} \mathrm{BT}\end{array}$ & $\pm 23.879 \mathrm{~km}$ & $\begin{array}{l} \pm 2 \text { hours } 10 \\
\text { min } \\
\text { (motorbike }\end{array}$ \\
\hline
\end{tabular}




\begin{tabular}{|c|c|c|c|c|c|}
\hline No & Plant & Information & Coordinate point & $\begin{array}{l}\text { Mileage From } \\
\text { Settlement } \\
\text { (Sungai } \\
\text { Gantang } \\
\text { Hamlet) } \\
\end{array}$ & $\begin{array}{l}\text { Travel Time } \\
\text { From } \\
\text { Settlement }\end{array}$ \\
\hline \multirow{5}{*}{5.} & \multirow{5}{*}{$\begin{array}{l}\text { The Potential } \\
\text { of Plants of } \\
\text { Mystical } \\
\text { Value }\end{array}$} & & & & and walk) \\
\hline & & & $\begin{array}{l}2^{\circ} 21 ' 59,9 " \mathrm{LS} \\
110^{\circ} 17 ' 14,7^{\prime \prime} \mathrm{BT}\end{array}$ & $\pm 23.879 \mathrm{~km}$ & $\begin{array}{l} \pm 2 \text { hours } 10 \\
\text { min } \\
\text { (motorbike }\end{array}$ \\
\hline & & $\begin{array}{l}\text { c. Gaharu } \\
\text { (Aquilaria } \\
\text { malaccensis) }\end{array}$ & $\begin{array}{l}2^{\circ} 20^{\prime} 29^{\prime \prime} \mathrm{LS} \\
110^{\circ} 15^{\prime} 49^{\prime \prime} \mathrm{BT}\end{array}$ & $\pm 16.840 \mathrm{~km}$ & $\begin{array}{l} \pm 1 \text { hours } 8 \\
\text { min } \\
\text { (motorbike) }\end{array}$ \\
\hline & & $\begin{array}{l}\text { a. Keketatai } \\
\text { (Antiaris } \\
\text { toxicaria) }\end{array}$ & $\begin{array}{l}2^{\circ} 20^{\prime} 19,0^{\prime \prime} \mathrm{LS} \\
110^{\circ} 15 ' 51,3^{\prime \prime} \mathrm{BT}\end{array}$ & $\pm 18.013 \mathrm{~km}$ & $\begin{array}{l} \pm 1 \text { hours } 13 \\
\min \text { (motor) }\end{array}$ \\
\hline & & $\begin{array}{l}\text { b. Pulai } \\
\text { (Alstonia } \\
\text { scholaris) }\end{array}$ & $\begin{array}{l}2^{\circ} 19^{\prime} 48^{\prime \prime} \mathrm{LS} \\
110^{\circ} 15^{\prime} 55^{\prime \prime} \mathrm{BT}\end{array}$ & $\pm 18.690 \mathrm{~km}$ & $\begin{array}{l} \pm 1 \text { hours } 16 \\
\text { min } \\
\text { (motorbike) }\end{array}$ \\
\hline
\end{tabular}

Data source: Research, 2020

\section{Kantong semar}

Kantong semar (Nepenthes sp.) is a one-of-a-kind plant with various color patterns. Pitcher plants are distinguished from other plants by their ability to attract and digest diverse insects, which are used to meet nutritional needs not met by the soil and the main nitrogen supply [5]. The presence of Nepenthes sp. was discovered not only at one point but also three neighboring

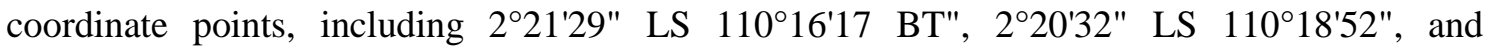
$02^{\circ} 20^{\prime} 34.2^{\prime \prime}$ latitude $110^{\circ} 18^{\prime} 48.4^{\prime \prime}$ east longitude at the location of Sebatu waterfall level 2 of the same type. With a distance of $20.600 \mathrm{~km}$, it takes 1 hour 22 minutes by motorcycle and automobile. The dominance index value was 0.264 , indicating that the Nepenthes $\mathrm{sp}$. discovered are not dominant [6].

\section{Bamboo}

Bamboo (Bambusa sp.) is a grass family plant that grows tall like a tree and uses segmented root rhizomes with one shoot in each segment to grow. Bamboo can grow in the shape of sympodial, monopodial, and amphipod clumps thanks to the utilization of rhizomes [1]. Bamboo is primarily found in Gantang Hamlet, where the object distance is $24.079 \mathrm{~km}$, which can be covered in 1 hour 53 minutes by motorbike or automobile, followed by a 15-minute walk along the river. Bamboo is used for matting, traps (fish traps), penangkin (goods carrying bags), bridge construction, and cattle pens [7].

\section{Potential of Medicinal Plants}

Forest species, such as bajakah and pasak bumi, are used as medicinal plants by the people of Kelukup Belantak hamlet. Bajakah (Spatholobus littoralis Hassk), often known as red bajakah, grows near the Belatak hamlet on the side of the Kediuk hill river. This herb is used as a stamina booster and body freshener by the community, who drink it straight or boil it first. Bajakah were 
found at $2^{\circ} 19^{\prime} 28^{\prime \prime} \mathrm{LS} 110^{\circ} 18^{\prime} 16^{\prime \prime}$ east longitude, with a distance of $28,670 \mathrm{~km}$ and 2 hours 21 minutes from the Gantang river, followed by a 55-minute walk through the forest and river. According to Fitriani (2020), the bark and stem of the red and white bajakah root plants contain secondary metabolites such as phenolics, tannins, and flavonoids, which have more potent antioxidant activity than vitamin C and vitamin E. Pasak bumi (Eurycoma longifolia Jack) grew on the banks of the Selingsing River. The roots of pasak bumi are used to treat situations like diabetes, stamina, and bodily strength [8]. Traditional medicine combines several herbs with properties to cure various diseases passed down from generation to generation since ancient times [9].

\section{Protected Plant Potential}

Plants are protected for the diminished natural populations, endemic distribution, reduced habitat, and unsustainable use. Protected plant species are preserved by avoiding removing them from the wild if discovered [9]. Ulin (Eusideroxylon zwageri), meranti (Shorea smithiana), and gaharu (Aquilaria malaccensis) are all rare and protected plant species found in Kelukup Belantak. Ulin is a Kalimantan native plant. This tree has been listed on the endangered species list since 2004 [10]. Meranti (Shorea smithiana) is a unique tree species to Kalimantan that grows from 150-400 meters above sea level in densely forested valleys and hillsides. Gaharu is a high-value non-timber forest product used to produce fragrances, pharmaceuticals, and ornaments. Table 1 illustrates the presence of plants.

The Potential of Plants with Mystical Value

Most communities, especially in the hamlet of Kelukup Belantak, still believe in something mysterious. They continue to practice the rituals and culture passed down from their forefathers. The majority of people still believe in something mystical [11]. Plants with mystical value such as ketatai tree's sap (Antiaris toxicaria) contain poison utilized in hunting. The public's idea that the sap of the ketatai tree can be lethal is based on a narrative in which the identity of the prince who teaches the ingredients for producing poison is revealed. They believe that the composition of the ketatai tree's poison is derived from the prince's mystical force. Pulai (Alstonia scholaris) is a big tree that has been used as a nesting site for the lalau/stinging honey bee (Apis dorsata) for hundreds of years. People think this tree has a powerful attraction or, as they call it, a 'ghost,' causing someone to have a solid desire to harvest honey despite the high/casualty danger. Alstonia scholaris also has a towering tree shape and a dense canopy. Thus, it has been thought to be a haunted house for ancestral spirits. It produces flowers with a particular perfume linked with rituals and appears to cover practically all plant surfaces when flowers bloom, giving it a white or yellow cream appearance [12]. 

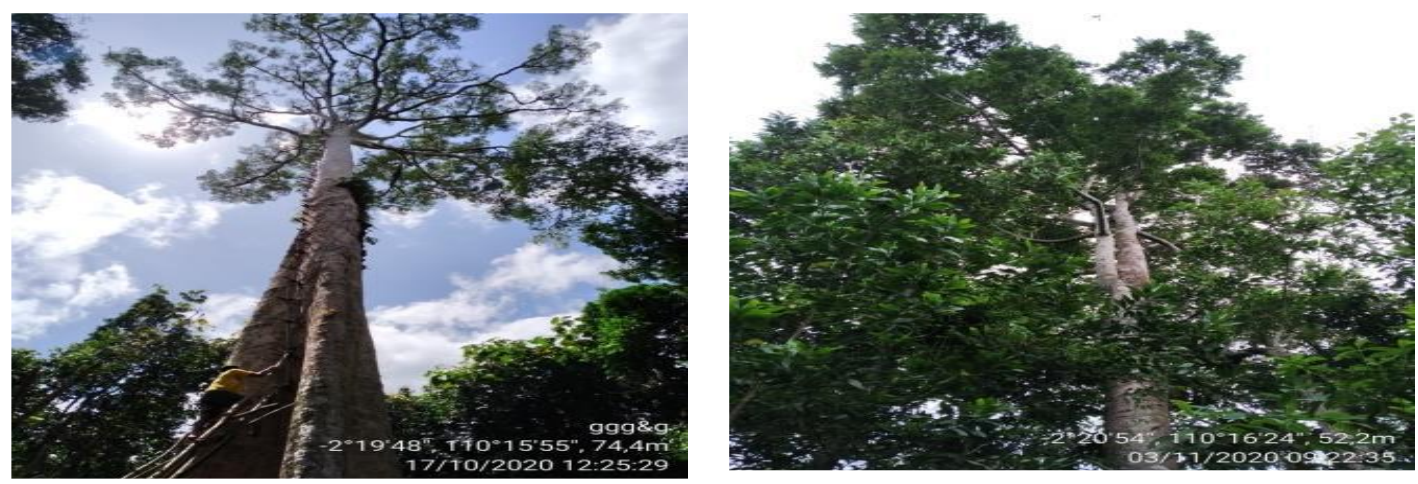

Figure 1 The potential of plants with mystical value: a. Lotus (Antiaris toxicaria), b. Pulai (Alstonia scholaris)

\section{B. Animal Potential}

Forest turtles (Dogania suplana), owa kelawat (Hylobates albibarbis), and honey bee (Apis koschevnikovi) were among the uncommon and distinctive species found at Kelukup Belantak Hamlet. Although the community still uses a hunting system, they continue to safeguard protected animals by enacting conservation regulations, one of which is an endeavor to create custom rules to regulate the protection of protected animals. If it is discovered that someone has hunted or killed a protected animal, they will be subject to customary law, which may include fines.

Table 2 Potential of animals found in Mekar Utama village with the distance of travel time measured from the settlement of Sungai Gantang hamlet

\begin{tabular}{|c|c|c|c|c|c|}
\hline No & Animals & Information & Coordinate point & $\begin{array}{l}\text { Mileage } \\
\text { From } \\
\text { Settlement }\end{array}$ & $\begin{array}{l}\text { Travel Time } \\
\text { From } \\
\text { Settlement }\end{array}$ \\
\hline 1. & $\begin{array}{l}\text { Unique } \\
\text { Animal } \\
\text { Potential }\end{array}$ & $\begin{array}{l}\text { Kura-kura Hutan } \\
\text { (Dogania } \\
\text { suplana) }\end{array}$ & $\begin{array}{l}2^{\circ} 21^{\prime} 13^{\prime \prime} \mathrm{LS} \\
110^{\circ} 17^{\prime} 13^{\prime \prime} \mathrm{BT}\end{array}$ & $\begin{array}{l} \pm 23.679 \\
\mathrm{~km}\end{array}$ & $\begin{array}{l} \pm 1 \text { hours } 47 \\
\text { min } \\
\text { (motorcycle) }\end{array}$ \\
\hline 2. & $\begin{array}{l}\text { Animal } \\
\text { Potential } \\
\text { Protected } \\
\text { The Potential }\end{array}$ & $\begin{array}{l}\text { Owa Kelawat } \\
\text { (Hylobates } \\
\text { albibarbis) }\end{array}$ & $\begin{array}{l}02^{\circ} 20^{\prime} 60,0^{\prime \prime} \mathrm{LS} \\
110^{\circ} 17^{\prime} 14,7 \mathrm{BT}\end{array}$ & $\begin{array}{l} \pm 23.479 \\
\mathrm{~km}\end{array}$ & $\begin{array}{l} \pm 1 \text { hours } 46 \\
\text { min } \\
\text { (motorcycle) }\end{array}$ \\
\hline 3. & $\begin{array}{l}\text { of Animals is } \\
\text { Utilized }\end{array}$ & $\begin{array}{l}\text { Lebah Madu } \\
\text { (Apis } \\
\text { koschevnikovi) }\end{array}$ & $\begin{array}{l}2^{\circ} 24 ' 22,1^{\prime \prime ~ L S ~} \\
110^{\circ} 13 ' 28,9^{\prime \prime} \mathrm{BT}\end{array}$ & $\pm 7.020 \mathrm{~km}$ & $\begin{array}{l} \pm 28 \text { min } \\
\text { (motorcycle) }\end{array}$ \\
\hline
\end{tabular}

Data source: Research, 2020.

\section{Kura-kura Hutan}

The forest turtles (Dogania suplana) are small and flat-bodied turtle species. Its shield is elongated or oblong. The back is blackish grey, brownish, or reddish with delicate patterns or patches. The yellowish line on the neck takes on a more distinct and appealing appearance. It was found at $2^{\circ} 21^{\prime} 13^{\prime \prime}$ LS $110^{\circ} 17^{\prime} 13^{\prime \prime} \mathrm{E}$ in the Batu Arang waterfall level 2 area. Flowing rivers with small and large rocks characterize its habitat. The river is home to many forest turtles and softshell turtles. However, tourists are rarely seen because they are more active at night. 
Owa Kelawat

Owa kelawat (Hylobates albibarbis) is indigenous species found exclusively in Kalimantan.

This creature lacks a tail and is a primate. It has brown-grey protective fur that varies in color and pattern. Hylobates albibarbis were identified by their sound near the Batu Arang waterfall in the morning. The sound was heard $2 \mathrm{~km}$ away from where the researchers listened. Like the red langur, Hylobates albibarbis is a diurnal primate that lives entirely in trees. The current state of their population is deteriorating. Between 1990 and 2006, there was a considerable drop. The International Union for Conservation of Nature (IUCN) labeled their population endangered in 2008 (Nijman, 2008).

\section{Honey Bee}

The community keeps the honey bees, such as Apis koschevnikovi and Trigona spp. They create artificial habitats as nests in two ways. The first method is by installing artificial beehives around trees. The second is to graft them onto the tree trunks by attaching artificial beehives to the existing beehives. After an extended period, when the honey bees have occupied the artificial nest, the hive is delivered and renovated at the farm.

\subsection{Socio-Cultural Ecotourism Potential}

Traditional rituals are performed at specific times or conditions in the hamlets of Kelukup Belantak and Sukaria. The ritual is an essential aspect of cultural preservation and a potential choice in interpretation activities [13].

Table 3 Interpretation of the socio-cultural potential found in Mekar Utama village with the distance of travel time measured from the Sungai Gantang hamlet settlement

\begin{tabular}{|c|c|c|c|c|c|}
\hline No. & $\begin{array}{l}\text { Socio- } \\
\text { cultural }\end{array}$ & Information & Coordinate & $\begin{array}{l}\text { Mileage } \\
\text { From } \\
\text { Settlement }\end{array}$ & $\begin{array}{l}\text { Travel Time } \\
\text { From } \\
\text { Settlement }\end{array}$ \\
\hline 1. & $\begin{array}{l}\text { Ethnic } \\
\text { groups }\end{array}$ & $\begin{array}{l}\text { Dayak } \\
\text { (Kendawangan Dua } \\
\text { Belas Membuluh } \\
\text { Lima), Melayu, } \\
\text { Batak }\end{array}$ & $\begin{array}{l}2^{\circ} 20^{\prime} 19 " \mathrm{LS} \\
110^{\prime} 15^{\prime} 50^{\prime \prime} \mathrm{BT}\end{array}$ & $\pm 17.470 \mathrm{~km}$ & $\begin{array}{l} \pm 1 \text { hour } 11 \\
\text { min } \\
\text { (motorcycle) }\end{array}$ \\
\hline 2. & Traditions & $\begin{array}{l}\text { a. Shifting } \\
\text { cultivation } \\
\text { b. House of Gotong } \\
\text { Royong }\end{array}$ & $\begin{array}{l}2^{\circ} 20^{\prime} 28^{\prime \prime} \mathrm{LS} \\
110^{\circ} 16^{\prime} 13^{\prime \prime} \\
\mathrm{BT} \\
2^{\circ} 20^{\prime} 27^{\prime \prime} \mathrm{LS} \\
110^{\circ} 15^{\prime} 47^{\prime \prime} \\
\mathrm{BT}\end{array}$ & $\pm 16.960 \mathrm{~km}$ & $\begin{array}{l} \pm 1 \text { hour } 17 \\
\text { min } \\
\text { (motorcycle) } \\
\pm 1 \text { hour } 9 \text { min } \\
\text { (motor) }\end{array}$ \\
\hline 3. & $\begin{array}{l}\text { Traditional } \\
\text { Rituals }\end{array}$ & $\begin{array}{l}\text { Traditional Rituals } \\
\text { held every year. } \\
\text { a. Menyimbag Adau } \\
\text { Memantas Akar } \\
\text { b. Tetebus Ulat } \\
\text { c. Tahun Baru } \\
\text { d. Sahab (Siang } \\
\text { Kampung) } \\
\text { e. Palas Kampung }\end{array}$ & $\begin{array}{l}2^{\circ} 20^{\prime} 17,5^{\prime \prime} \mathrm{LS} \\
110^{\circ} 15^{\prime} 52,6^{\prime \prime} \\
\mathrm{BT}\end{array}$ & $\pm 17.470 \mathrm{~km}$ & $\begin{array}{l} \pm 1 \text { hour } 11 \\
\text { min } \\
\text { (motorcycle) }\end{array}$ \\
\hline
\end{tabular}




\begin{tabular}{|c|c|c|c|c|c|}
\hline No. & $\begin{array}{l}\text { Socio- } \\
\text { cultural }\end{array}$ & Information & Coordinate & $\begin{array}{l}\text { Mileage } \\
\text { From } \\
\text { Settlement }\end{array}$ & $\begin{array}{l}\text { Travel Time } \\
\text { From } \\
\text { Settlement }\end{array}$ \\
\hline 4. & Arts & $\begin{array}{l}\text { Dukun Pitara Dance } \\
\text { a. Brinsit (Women) } \\
\text { b. Beganjak (Men) }\end{array}$ & $\begin{array}{l}2^{\circ} 20^{\prime} 17,5^{\prime \prime} \mathrm{LS} \\
110^{\circ} 15^{\prime} 52,6^{\prime \prime} \\
\mathrm{BT}\end{array}$ & $\pm 17.470 \mathrm{~km}$ & $\begin{array}{l} \pm 1 \text { hour } 11 \\
\text { min } \\
\text { (motorcycle) }\end{array}$ \\
\hline 5. & $\begin{array}{l}\text { Special } \\
\text { foods }\end{array}$ & $\begin{array}{l}\text { Lemang, Kiping- } \\
\text { kiping, Bahaman } \\
\text { (emping/melinjo } \\
\text { chips) }\end{array}$ & $\begin{array}{l}2^{\circ} 20^{\prime} 17,5^{\prime \prime} \mathrm{LS} \\
110^{\circ} 15^{\prime} 52,6^{\prime \prime} \\
\mathrm{BT}\end{array}$ & $\pm 17.470 \mathrm{~km}$ & $\begin{array}{l} \pm 1 \text { hour } 11 \\
\text { min } \\
\text { (motorcycle) }\end{array}$ \\
\hline \multirow[t]{3}{*}{6.} & $\begin{array}{l}\text { Historic } \\
\text { sites/ } \\
\text { Sacred }\end{array}$ & a. Kayu Ara & $\begin{array}{l}2^{\circ} 19^{\prime} 27^{\prime \prime} \mathrm{LS} \\
110^{\circ} 18^{\prime} 13^{\prime \prime} \\
\text { BT }\end{array}$ & $\pm 26.840 \mathrm{~km}$ & $\begin{array}{l} \pm 1 \text { hour } 55 \\
\text { min } \\
\text { (motorbike } \\
\text { and walk) }\end{array}$ \\
\hline & & b. Bukit Batu & $\begin{array}{l}2^{\circ} 14^{\prime} 45.0^{\prime \prime} \mathrm{LS} \\
110^{\circ} 19^{\prime} 22,8^{\prime \prime} \\
\mathrm{BT}\end{array}$ & $\pm 26.926 \mathrm{~km}$ & $\begin{array}{l}1 \text { hour } 42 \mathrm{~min} \\
\text { (motorcycle) }\end{array}$ \\
\hline & & $\begin{array}{l}\text { c. Batu Keramat } \\
\text { Springs }\end{array}$ & $\begin{array}{l}2^{\circ} 19^{\prime} 36,9^{\prime \prime ~ L S ~} \\
110^{\circ} 18^{\prime} 09,3^{\prime \prime} \\
\text { BT }\end{array}$ & $\pm 27.300 \mathrm{~km}$ & $\begin{array}{l} \pm 2 \text { hours } 1 \\
\text { min } \\
\text { (motorbike } \\
\text { and walk) }\end{array}$ \\
\hline 7. & $\begin{array}{l}\text { Folklores/ } \\
\text { Myths }\end{array}$ & $\begin{array}{l}\text { Mambang Tujuh } \\
\text { Beradik (Kumpang } \\
\text { Prayah)/ Tolak bala } \\
\text { a. Apeaji Manang } \\
\text { b. Selungsung Angin } \\
\text { c. Selungsung Urat } \\
\text { d. Selungsung } \\
\text { Batang } \\
\text { e. Selungsung Daun }\end{array}$ & $\begin{array}{l}2^{\circ} 20^{\prime} 17,5^{\prime \prime} \mathrm{LS} \\
110^{\circ} 15^{\prime} 52,6^{\prime \prime} \\
\mathrm{BT}\end{array}$ & $\pm 17.470 \mathrm{~km}$ & $\begin{array}{l} \pm 1 \text { hour } 11 \\
\text { min } \\
\text { (motorcycle) }\end{array}$ \\
\hline
\end{tabular}

Data source: Research, 2020

\section{Ethnic group}

The potential for ecotourism based on socio-cultural values in Mekar Utama village was found in the hamlets of Sukaria and Kelukup Belantak. They have a common ancestor, namely the Dayak tribe (Kendawangan Dua Belas Membuluh Lima), whose tradition of shifting cultivation and gotong royong (work together). Shifting cultivation is a hereditary culture that is still practiced nowadays. It is carried out to obtain maximum yields. Meanwhile, the ethnical in the Sungai Gantang hamlet were mixed and are dominated by the Malays.

\section{Tradition}

Land clearing, planting plants, and building houses are part of the gotong royong, especially for the less fortunate. Every community that participates in gotong royong is unpaid and uninvolved. Gotong royong is a hereditary tendency passed down from generation to generation. Tradition emerges from the customs of previous generations, which are then imitated and carried out by the following [8].

\section{Traditional Rituals}

Traditional ceremonies are linked to various functions and have significant importance in society [8]. Traditional rites were found in the hamlet of Kelukup Belantak. They are performed 
every year, including 1) Ritual Adat Menimbang Adau Memantas Akar is a traditional ceremony used to prepare land for farming. It is commonly performed in January and March. 2) Tetebus Ulat is used in a ritual to protect community plants from pests and diseases. 3) Tahun Baru or potong padi (cutting the paddy) is a traditional harvest rite in which a tiny piece of the harvest is offered to Jubata (God/God who follows it). 4) Sahab is a traditional ritual in which puppets made of pulai wood and offerings to Jubata are used to reject the possibility of disease epidemics. 5) Palas Kampung is a traditional rite in which people or villages atone for their mistakes by sacrificing Jubata to avoid tragedy. According to the results of an interview with the traditional leader (Pak Ro'I), all of these ancient rites were still valid because they have been passed down from generation to generation and were considered an obligation as thanksgiving.

Arts

The community regards traditional art as enjoyable entertainment because it is seen as a means of facilitating their prayers and hopes or as a link between ritual values and the supportive community's principles of simplicity and collaboration [8]. The Dukun Pitara Dance, a dance performed by men or Beganjak and women or Bringsit while conducting ancient rituals and accompanied by music called Begandang, is also present in the hamlet of Kelukup Belantak.

\section{Special foods}

Special food takes on the character and identity of a place, defining its taste such that people recall it when they eat the area's typical meal. Food at a tourist destination must be introduced as a gastronomic feature of the region and its appealing tourist attractions. Promoting traditional foods is one of the most critical aspects of the food-tourism interaction [8]. Lemang, kipingkiping, and bahaman are popular dishes in Dusun Kelukup Belantak. These foods are used as ingredients/offerings in rituals and consumed in general. Some are created at the Demung Adat house.

\section{Historic or Sacred Places}

Sacred places were discovered in three sites: 1) Batu Keramat Spring is one of the places where traditional rituals are performed in the shape of a bathing pool that is relatively wide and green in color with a depth of around 3 meters. 2) Ara tree (Ficus) has long been revered by the community as a sacred tree with inhabitants. They perform rituals here because the impression provided when going through the streets is a visual delicacy that generates mystical energy in a spiritual environment. This tree is mysterious, but it also plays a significant function in the forest's wildlife ecosystem. Ficus fruit is a source of food for bats, monkeys, langurs, and orangutans, as well as a staple diet for pigeons, hornbills, ara-parrots, and finches in forest habitats, particularly in Kalimantan [14]. 3) Bukit Batu is one of the most unusual sights due to its giant boulders and little flora. People consider the hill a sacred site because they believe it is an excellent spot to contemplate. People believe that this hill is an excellent place to meditate, or as the community calls it, 'beniat,' to make it sacred. It is held by people who want to gain knowledge, or supernatural powers, in places with mystical solid energy, such as sacred places 
away from society. Ardiyanto (2015) said that Arjuna was dubbed Begawan Ciptaning when he was imprisoned in the lakon Arjuna Wiwaha, which was interpreted by all subjects as gaining creative silence while he was imprisoned, allowing him to understand closeness to the creator and grant any request.

\section{Folklores/Myths}

The Mambang Tujuh Beradik (Kumpang Prayah) or ritual tolak bala from the community established in society in the past dan was the hallmark of the village of Kelukup, is still being practiced nowadays. Myths are traditional tales, not contemporary tales [4]. Apeaji Manang, Selungsung Angin, Selungsung Urat, Selungsung Batang, Selungsung Daun are the stories of the Mambang Tujuh Beradik (Kumpang Prayah). This narrative teaches us that we should not be arrogant and believe that we can solve everything with reasoning and science. In addition, humanity must have faith/spirituality towards their creators while surrendering to the creator's decision. When urging children who will migrate to remember their homeland, the community tells them this story.

\subsection{Interpretation of Ecotourism Potential}

Mekar Utama village could be developed by planning through three routes along $48.8 \mathrm{~km}$, and the time required was 2 hours 47 minutes using motorcycle, car, and walking. The interpretation track was taken for 25 minutes with a distance of $\pm 4 \mathrm{~km}$. [3].

\section{A. $\quad$ Gantang Sungai Hamlet Route}

The Sungai Gantang Interpretation Line was $6.5 \mathrm{~km}$ long and took 26 minutes by motorcycle or car from the entrance to the Sungai Gantang hamlet. This route connected Sukaria Hamlet to Kelukup Belantak Hamlet's ecotourism potential.

\section{B. Sukaria Hamlet Route}

The Sukaria Hamlet Interpretation Line was $5.3 \mathrm{~km}$ long and ran between Sungai Gantang Hamlet and Kelukup Belantak Hamlet. It took 21 minutes to travel from the Sungai Gantang Hamlet to the Kelukup Belantak Hamlet's boundary. The journey can be completed on a motorcycle or in a car. This path reveals the potential of the animals used, notably honey bees farming.

\section{C. $\quad$ Kelukup Belantak Hamlet Route}

The interpretation track with the highest ecotourism potential was Kelukup Belantak Hamlet. A motorcycle or car was used to explore the $37 \mathrm{~km}$ for 2 hours, although it will be continued on a walk at some tourist attractions. Kantong semar, bambu, bajakah, pasak bumi, ulin, meranti, gaharu, ketatai, pulai, forest turtles, owa kelawat, shifting cultivation, gotong royong, batu keramat spring, ara tree, bukit batu, and dayak ethnic settlements were among the ecotourism potential diversity discovered. 
D. Biological and Socio-Cultural Ecotourism Interpretation Tracks

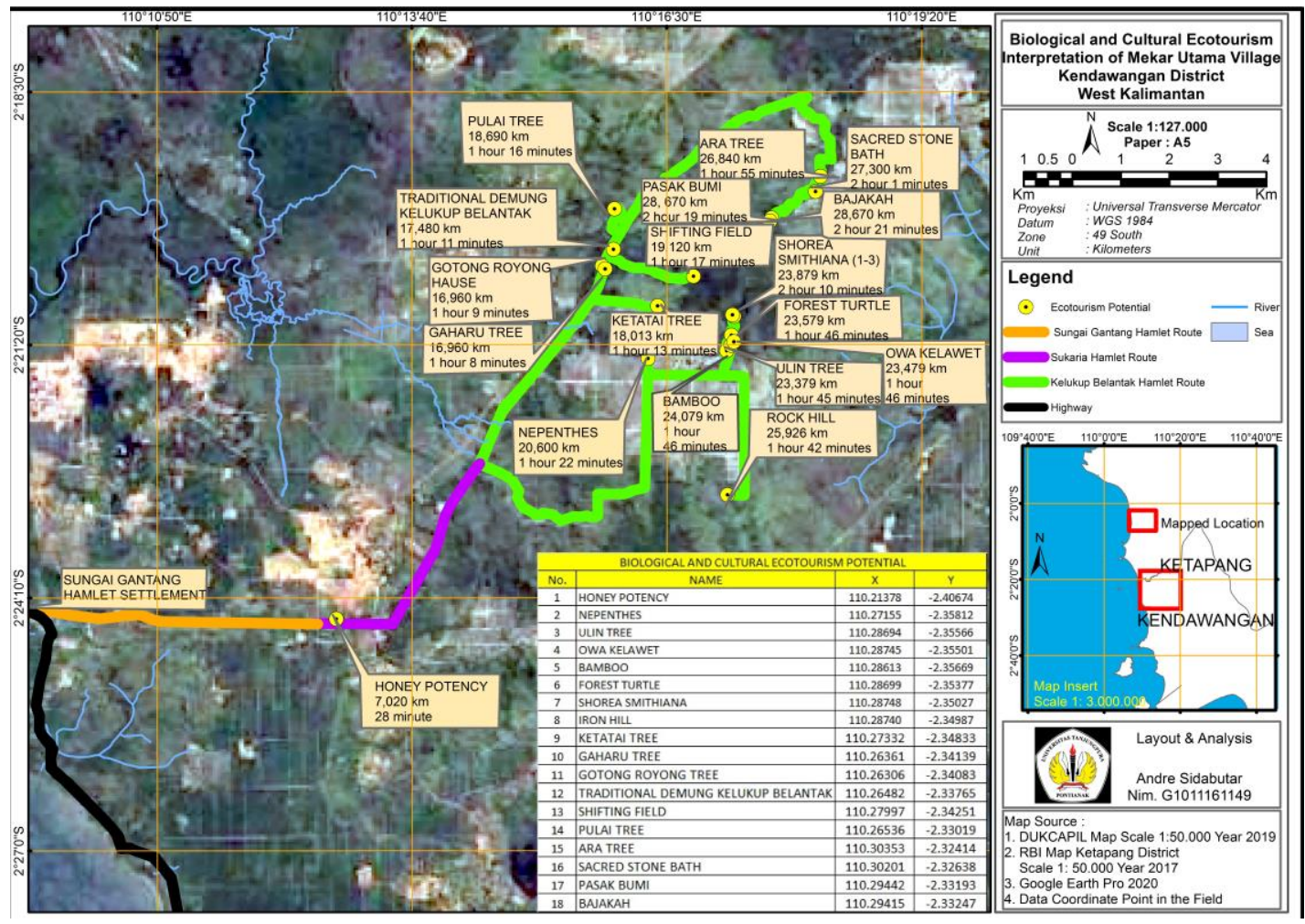

Figure 2 Map of Biological and Socio-Cultural Ecotourism Interpretation Tracks in Mekar Utama Village

\section{Conclussion}

Mekar Utama Village was suitable for interpretation with 18 biological and socio-cultural ecotourism potentials. There were nine potential plants. Other potential attractions were three species of animals and six objects of socio-cultural. The potential coordinates of the item can be discovered near the hamlets of Kelukup Belantak, Sukaria, and Sungai Gantang.

\section{REFERENCES}

[1] J. Butcher, "Ecotourism, NGOs and Development," in A Critical Analysis, New York, Routledge, 2007, p. 208.

[2] R. R. Akmal, G. D. Winarno, and T. Santoso, "Pemetaan Jalur Interpretasi Ekowisata Di Desa Pahmungan, Kabupaten Pesisir Barat," Jurnal Hutan Tropis, vol. 9, no. 1, pp. 173-180, 2021.

[3] R. Islamiati, S. M. Kartikawati and T. Widiastuti, "Interpretasi Potensi Ekowisata Dusun Darok Kecamatan Bonti Kabupaten Sanggau Kalimantan Barat," Jurnal Hutan Lestari, vol. 8, no. 2, pp. 350-360, 2020.

[4] Hambali. "Pengetahuan Mistis Dalam Konteks Islam Dan Filsafat Ilmu Pengetahuan", Jurnal Substantia, vol. 13, no. 2, 2011.

[5] E. Gorb, A. Peressadko, E. Arzt and V. Kastner, "Structure and properties of the glandular surface in the digestive zone of the pitcher in the carnivorous plant Nepenthes ventrata and its role in insect trapping and retention," Journal of Experimental Biology, vol. 207, no. 17, pp. 2947-2963, 2004.

[6] I. Dewantara, H. Ardian, "Keanekaragaman Jenis Kantong Semar (Nepenthes spp) di Kebun Raya Sambas Kecamatan Subah Kabupaten Sambas Kalimantan Barat," Jurnal Hutan Lestari, vol. 6, no. 3, 2018.

[7] M. Z. Charomaini, Budidaya Bambu Jenis Komersial, IPB Press, Bogor, 2014.

[8] R. N. Okech, "Developing Culinary Tourism-The Role of Food as a Cultural Heritage in Kenya," in Proceedings of the Second International Conference on Global 
Business, Economics, Finance and Social Science (GB14 Chennai Converence), Chennai, India, 2014.

[9] P. Siswoyo, Tumbuhan Berkhasiat Obat, PT. Absolut, Yogyakarta, 2008.

[10] J. Lamoreux, H. R. Akcakaya, L. Bennun and N. J. Collar, Value of the IUCN Red List, 2003.

[11] W. S. Hassanudin, Ensiklopedia Sastra Indonesia (Edisi Revisi), Titian Ilmu, Bandung, 2009.

[12] Nur'aini, Syamsuardi and A. Arbain, "Tumbuhan Ficus L. (Moraceae) di hutan konservasi Prof. Soemitro Djojohadikusumo, PT. Tidar Kerinci Agung (TKA), Sumatera Barat," Jurnal Biologi, vol. 2, no. 4, pp. 235-241, 2013.

[13] Saryana and A. Muin, Upacara dan Rumah Adat: Suku Dayak dan Melayu di Kalimantan Barat, Romeo Grafika, Pontianak, 2003.

[14] V. Nijman, Hanging in the Balance: An Assessment of trade in Orang-utans and Gibbons in Kalimantan, Malaysia, TRAFFIC Southeast Asia, Selangor, 2005. 